\title{
Selebriti dalam Digital Activism Tentang Kekerasan Terhadap Perempuan di YouTube
}

\author{
Eni Maryani ${ }^{1}$, Sarah Astari ${ }^{2}$ \\ Universitas Padjadjaran
}

\begin{abstract}
ABSTRAK
Penelitian ini membahas keterlibatan para selebriti dalam film '16 days of Activism' terkait isu kekerasan terhadap perempuan yang diunggah dalam YouTube. Isu kekerasan terhadap perempuan masih perlu disebarluaskan ke masyarakat akan tetapi kuatnya nilai-nilai patriarki menjadikan isu ini cenderung terpinggirkan. Merujuk pada fenomena tersebut maka penggunaan beragam media dan aktor menjadikan sangat penting bagi proses advokasi untuk melawan tindak kekerasan terhadap perempuan. Metode yang digunakan studi kasus dengan pengumpulan data melalui wawancara mendalam, observasi dan studi dokumentasi. Penelitian mengungkapkan bahwa sinergi sebagai survivor, selebriti dan juga aktivis menjadi kekuatan bagi Hannah Ar Rashid untuk mengangkat wacana tentang kekerasan terhadap perempuan dan melibatkan selebriti lain dalam produksi filmnya untuk advokasi, YouTube adalah salah satu media digital yang mampu mempermudah advokasi melalui film. Film '16 Days of Activism' di YouTube merupakan salah satu bentuk digital activism yang dilakukan para selebriti. Film advokasi yang melibatkan para selebriti mampu menjadi daya tarik bagi khalayak untuk menerima dan memahami isu kekerasan terhadap perempuanAbstrak ditulis secara ringkas dan faktual, meliputi latar belakang, tujuan penelitian, metode penelitian, hasil penelitian, simpulan dan saran. Abstrak ditulis dalam bahasa Inggris dan Indonesia, panjang abstrak berkisar antara 200-250 kata dalam satu paragraf, huruf Times New Roman 11 dan spasi 1.
\end{abstract}

Kata-kata Kunci: selebriti, digital activism, kekerasan terhadap perempuan, media digital, YouTube

\section{Celebrity in Digital Activism about Violence toward Woman in YouTube}

\begin{abstract}
This study discusses the involvement of celebrities in the film "16 Days of Activism" regarding the issue of violence against women which was uploaded on YouTube. The issue of violence against women still needs to be dispersed among the community, but this issue tend to be marginalized because of strong patriarchal values. Referring to this phenomenon, the use of various media and actors makes it very important for the advocacy process to resist violence against women. The methods used in this research were case study and data collection through in-depth interviews, observation and documentation studies. The research reveals the synergy of survivors, celebrities and activists are forces that Hannah Ar Rashid used to raise discourse on violence against women and other celebrities were involved in her film production for advocacy, YouTube is one of the digital media that can facilitate advocacy through film. The film "16 Days of Activism" on YouTube is one form of digital activism by celebrities. Advocacy films that involve celebrities can be an attractive media for the audience with which they can be exposed and learn to understand the issue of violence against women..
\end{abstract}

Keywords: celebrities, digital activism, violence against women, digital media, YouTube

Korespondensi: Dr. Eni Maryani, Dra., M.Si. Universitas Padjadjaran. Jln. Raya Bandung-Sumedang Km.21 Jatinangor. Email: eni.maryani@unpad.ac.id 


\section{PENDAHULUAN}

Upaya untuk mengatasi kekerasan terhadap perempuan masih menjadi pekerjaan rumah bagi masyarakat Indonesia. Menurut data Komnas Perempuan selama 2017 terdapat 348.446 kasus kekerasan terhadap perempuan yang dilaporkan di 34 provinsi. Sebanyak 335.062 ditangani oleh Pengadilan Agama, serta 13.384 kasus dilaporkan dan ditangani oleh 237 lembaga mitra pengada layanan (Komnas Perempuan, 2018). Jumlah korban tersebut berdasarkan yang dilaporkan pada lembagalembaga yang kemudian menanganinya, jumlah yang sebenarnya diperkirakan lebih dari yang dilaporkan. Kasus kekerasan terhadap perempuan sering disembunyikan karena dianggap masalah pribadi, sesuatu yang memalukan dan korban seringkali disalahkan oleh lingkungan sebagai pemicu terjadinya kekerasan.

Berkembangnya media online mendapat catatan tersendiri dari Komnas Perempuan, terkait dengan berkembangnya kekerasan terhadap perempuan dalam ranah cybercrime. Komnas Perempuan mencatat adanya kekerasan terhadap perempuan di dunia maya, penghakiman digital bernuansa seksual, kasus persekusi online dan offline dokter F, situs dan aplikasi, prostitusi online berkedok agama di ayopoligami.com dan Nikahsirri.com, kerentanan ekspolitasi seksual anak perempuan di dunia maya, dan eksploitasi tubuh perempuan (Komnas Perempuan, 2018).

Merujuk pada data Komnas Perempuan maka upaya untuk mengatasi tindak kekerasan terhadap perempuan tidak saja sulit akan tetapi semakin kompleks. Tidak heran jika banyak lembaga dan aktor yang harus terlibat dalam upaya penghapusan kekerasan terhadap perempuan. Salah satu latar belakang terjadinya kekerasan terhadap perempuan adalah berkembangnya stereotip tentang gender di masyarakat yang umumnya merugikan perempuan. Sebagai contoh ketika terjadi perkosaan seringkali dianggap kesalahan perempuan karena menggunakan pakaian yang minim. Sementara berdasarkan data Komnas Perempuan korban perkosaan dialami oleh banyak perempuan dari berbagai kalangan dan dengan cara berpakaian yang beragam (Komnas Perempuan, 2018). Menurut penelitian Montiel keterlibatan institusi media berita atau news media organizations memiliki kekuasaan atau kekuatan untuk memperkuat kesetaraan gender melalui upaya mendesiminasikan tentang streotip tentang gender yang berkembang di masyarakat (Montiel, 2015; 182-193).

Selain itu terdapat pula beragam upaya yang menarik dan penting terkait dengan upayaupaya mendukung advokasi tentang kekerasan terhadap perempuan. Indonesia for Humanity (IKa) merupakan salah satu institusi masyarakat sipil yang mengembangkan gerakan berbasis solidaritas sosial untuk mendukung gerakan sosial terkait isu kekerasan terhadap perempuan (Maryani, 2018; 12-17).

Merlyna Lim dalam salah satu risetnya mengungkapkan bahwa kegiatan advokasi melalui digital yang kemudian diistilahkan dengan digital activism memiliki tantangan terkait adanya perbedaan tentang simpati atau respon khalayak terhadap advokasi yang di lakukan di media digital dengan respon atau 
partisipasi mereka dalam kehidupan nyata (Lim, 2013; 636-657). Walaupun jika merujuk pada temuan Lim maka perlu disadari bahwa media digital memiliki kelemahan terkait advokasi, akan tetapi penggunaan media digital untuk beragam advokasi tetap berkembang dalam berbagi isu dan dilakukan oleh beragam kelompok.

Penggunaan media digital dalam berbagai kegiatan advokasi juga berkembang seperti Aliansi laki-laki Baru (Maryani, Rahmawan, Preciosa, 2017) dan Magdelene.co yang mengembangkan media digital perempuan dan digunakan untuk memberi alternative berbagai pandangan tentang perempuan (Maryani \& Adiprasetio, 2017; 111-124). Selain itu terdapat pula gerakan Literasi Indonesia yang mengembangkan media digital Literasi.co yang pengelolaannya berbasis kooperasi dan solidaritas sosial. Literasi.co mengangkat isu-isu atau masalah yang dihadapi masyarakat yang dimarjinalkan atau kalangan grass root (Maryani \& Adiprasetio, 2017).

Merujuk pada berbagai penelitian di atas apa yang dikembangkan Hanah Al Rashid dalam advokasi tentang kekerasan terhadap perempuan menjadi penting. Pertama, peran Hannah sebagai inisiator dalam kegiatan advokasi tersebut. Selain itu upaya Hannah melibatkan selebritis dalam film advokasi berjudul “\#16 Days of Activism 2017" yang diunggah di YouTube. Ini merupakan strategi yang diawali dengan advokasinya pada sesama selebritis yang diasumsikan akan menjadi daya tarik bagi khalayak yang lebih luas.

Penelitian ini didasari beberapa pertanyaan berikut ; 1) Bagaimana kekuatan Hannah Ar
Rashid dalam proses advokasi tentang kekerasan terhadap perempuan?, 2) Mengapa YouTube dipilih sebagai media advokasi film, "16 Days Activism'?, 3) Bagaimana keterlibatan selebriti dalam film '\#16 Days of Activism2017' di YouTube sebagai digital activism? 4) Bagaimana pandangan khalayak terkait keterlibatan selebriti dalam film "16 Days of Activism 2017"?, Pertanyaan-pertanyaan tersebut menjadi dasar untuk mencapai tujuan yang ingin dicapai dari penelitian ini dan dipaparkan dalam artikel ini.

\section{Digital Activism Sebagai sebuah Konsep dan} Aktivitas

Penggunaan istilah digital activism hingga kini masih menjadi polemik karena terdapat banyak pihak yang saling berargumentasi mengenai pengertian dari digital activism ini sendiri. Hal tersebut karena digital activism dianggap bukan terminologi yang tepat untuk menggambarkan kegiatan dan penggunaan teknologi digital untuk kegiatan aktivisme (Shah, Sivitanides, dan Mehta, 2013).

Terlepas dari polemik yang ada, Joyce (2010) mencoba mengartikan digital activism sebagai sebuah aktivitas atau praktek yang mendalam dan eksklusif. "mendalam" mencakup semua praktik kampanye sosial dan politik yang menggunakan infrastruktur jaringan digital dan “eksklusif” karena tidak termasuk praktek latihan di dalamnya. Adanya unsur mendalam dan eksklusif pada pengertian digial activism tersebut menjdika digital activism dianggap sebagai terminologi yang paling tepat untuk mendiskusikan berbagai hal terkait kegiatan aktivisme yang menggunakan infrastruktur 
jaringan digital (Shah, Sivitanides, dan Mehta, 2013).

Digital activism sendiri dinggap telah memiliki sejarah perkembangan. Athina Karatzogianni membagi perkembangan digital activism ke dalam empat gelombang. Gelombang pertama dimulai pada tahun 1994 dengan adanya gerakan Zapatista di Meksiko dan gerakan antiglobalisasi, juga munculnya media-media alternatif. Pada gelombang kedua, didominasi oleh meningkatnya kegiatan digital activism yang berkaitan dengan anti perang Iraq yang terentang mulai tahun 2001 hingga 2007. Kemudian pada gelombang ketiga (setelah tahun 2007), kegiatan digital activism mulai menyebar ke berbagai negara di luar Amerika Serikat dan Eropa. Pada gelombang keempat, pengarus utamaan (mainstreaming) digital activism didominasi oleh diskusi-diskusi yang berskala lebih besar, terbentang pada tahun 2010 hingga 2013 (Karatzogianni, 2015).

\section{Daya Tarik Selebriti bagi Masyarakat}

Selebriti diartikan oleh Rojek (2001; 5) sebagai "the relatively small proportion of definitions that accentuate the individuality, the celebrity as a person, often refer to its innate qualities, skills, authenticity, star quality or charisma". Pengertian ini dilengkapi oleh Grigoriadis (2005) yang mengatakan bahwa selebriti adalah individu yang telah mencapai suatu tingkat ketenaran yang membuat mereka sangat dikenal dalam masyarakat. Berkembangnya budaya selebriti telah melahirkan tingkat keingintahuan yang intensif dan menimbulkan spekulasi tentang kepribadian dari selebriti tersebut. Selebriti dianggap telah menjadi pusat perhatian masyarakat karena favorabilitas, kepribadian, reputasi, serta kisah masa lalunya (Driessens, 2013). Hal ini terjadi karena adanya media yang selalu menyorotnya sehingga ia menjadi terkenal dan berbeda daripada orang lain.

Berdasarkan pengertian-pengertian tersebut, istilah "selebriti" nyatanya tidak hanya dapat diberikan kepada individu yang bekerja dalam industri hiburan, namun juga individu lain yang memiliki karakteristik seperti disebutkan oleh Driessens, termasuk pebisnis, atlit, dokter, hingga pejabat negara. Dengan segala eksposur yang diterima oleh seorang selebriti, maka apa yang terjadi dalam hidup mereka seringkali menjadi hal yang menarik untuk dibahas walaupun hal tersebut juga bisa saja terjadi dalam hidup orang lain. Pada era digital ini, pertukaran informasi dalam masyarakat terjadi dengan sangat cepat sehingga selebriti tak hanya bergantung pada media untuk mendapatkan eksposur, namun juga melalui berbagai platform digital seperti media sosial.

Eksposur yang didapatkan oleh para individu ini banyak dimanfaatkan sebagai sarana menyebarluaskan sebuah ide, mulai dari informasi yang mendesak, kabar-kabar gembira, hingga aktivitas sosial yang termasuk di dalamnya kampanye-kampanye non-profit untuk orang yang membutuhkan. Saat ini daya tarik selebriti juga dimanfaatkan tidak saja oleh kalangan bisnis atau untuk kepentingan komersial akan tetapi berbagai kepentingan sosial. Berbagai lembaga yang bergerak dalam pemberdayaan masyarakat, perubahan sosial atau berbagai kampanye baik untuk kesehatan, 
lingkungan, pendidikan maupun isu gender. Ini menjadi peluang para selebritis memanfaatkan kepopulerannya untuk kepenntingan yang lebih luas dan bukan hanya terkait dengan kepentingan komersial.

\section{Kekerasan terhadap Perempuan Sebagai} Sebuah Isu

The Declaration on the Elimination of Violence Against Women, yang diadopsi oleh Dewan Keamanan PBB tahun 1993, menyebutkan bahwa yang dimaksud dengan kekerasan terhadap perempuan adalah:

"Setiap tindakan berdasarkan perbedaan
jenis kelamin yang berakibat atau mungkin
berakibat kesengsaraan atau penderitaan
perempuan secara fisik, seksual, dan
psikologis, termasuk ancaman tindakan
tertentu, pemaksaan, atau perampasan
kemerdekaan secara sewenang-wenang,
baik yang terjadi di depan umum atau
dalam kehidupan pribadi." (Kelompok
Kerja "Convention Watch" Pusat Kajian
Wanita dan Gender Universitas Indonesia,
2000)

Harkristuti Harkriswono mengutip

Schuler, mendefinisikan kekerasan terhadap perempuan sebagai setiap kekerasan yang diarahkan kepada perempuan hanya karena mereka perempuan (any violent act perpetrated on women because they are women) (Harkriswono, 2000).

Jumlah kasus kekerasan terhadap perempuan selalu mengalami kenaikan setiap tahunnya, seperti yang tercantum dalam berbagai laporan organisasi salah satunya Catatan Tahunan Komas Perempuan. Bentuk kasusnya juga beragam, mulai dari ranah personal, publik, hingga ranah nasional yang menjadi tanggung jawab negara. Catahu Komnas Perempuan tahun 2018 juga memberikan perhatian pada beberapa persoalan lain seperti munculnya pola kekerasan terhadap perempuan di dunia maya, femisida \& kekerasan dalam rumah tangga, kekerasan yang dilakukan oleh pejabat publik \& tokoh masyarakat, dan lain-laian (Komnas Perempuan, 2018).

Pemberitaan tentang isu-isu atau kasuskasus terkait dengan kekerasan terhadap perempuan seringkali lebih memberi rasa takut bagi perempuan dan dibandingkan memberikan pemahaman yang benar tentang peristiwa yang terjadi pada masyarakat. Penjelasan tentang kekerasan yang dilakukan seringkali justru menghasilkan rasa takut atau jijik karena memberikan informasi detil tentang kejahatan yang dilakukan. Seringkali pemberitaan atau liputan yang dibuat juga menjadikan pelaku seakan-akan menjadi pihak yang tidak bersalah atau korban dari perempuan yang dianggap menggoda atau mendorong mereka untuk melakukan kekerasan tersebut.

Untuk media-media yang memuat isu-isu kriminalisasi maka isu tentang kekerasan terhadap perempuan memiliki kecenderungan untuk dikomodifikasi sehingga menjadi bahan berita yang kontroversial. Oleh karena itu pemberitaan yang dilakukan seringkali melanggar hak-hak perempuan sebagai korban bahkan seringkali dikatangan para korban tindak kekerasan terhadap perempuan mengalami apa yang disebut sebagai reviktimisasi. Sebagai korban kekerasan mereka menjadi korban media yang berusaha mengeksploitasi mereka untuk mendapat cerita yang kemudian dijadikan komoditas bagi media mereka untuk 
mendapatkan sebanyak-banyaknya keuntungan bagi media atau komodifikasi. Pemberitaan tentang kasus kekerasan terhadap perempuan tidak lagi dinilai sebagai berita yang layak atau bernilai untuk diketahui masyarakat akan tetapi pemberitaan tersebut dinilai sebagai komoditas yang nilainya tergantung berapa banyak berita itu dapat menghasilkan keuntungan ekonomi.

\section{METODE PENELITIAN}

Penelitian ini menggunakan studi kasus dengan pendekatan kualitatif yang berusaha mengangkat kasus berbasis pada konteks yang diteliti untuk menafsirkan dan memahami fenomena yang diamati. Pemaparan fenomena yang diteliti bersumber dari beragam praktik seperti percakapan, foto, rekaman, dan catatan yang dibuat peneliti. Selain itu penelitian ini juga melibatkan pendekatan interpretif terhadap fenomena yang diteliti berdasarkan kepekaan peneliti terhadap fenomena yang diamati (Denzin dan Lincoln, 2005; 3, Cresswell, 2007; 26).

Sebagai sebuah studi kasus maka penelitian ini juga mencoba mengeksplorasi kasus secara mendalam melalui pengumpulan data yang detil (Creswell, 2007 ; 73) dan mencakup pertanyaan-pertanyaan "how" (bagaimana) dan "why" (mengapa), serta pada tingkat tertentu juga menjawab pertanyaan "what" (apa/apakah), dalam kegiatan penelitiannya (Yin, 2000; 25). Sebagai kasus dalam riset ini adalah keterlibatan selebriti dalam film YouTube yang dibuat oleh Hannah Al Rashid yang berjudul "\#16 Days of Activism 2017”. Selain diinisiasi oleh seorang selebriti film ini juga melibatkan 27 selebriti Indonesia lainnya dan aktivis.

$$
\text { Pengumpulan data dilakukan melalui }
$$
wawancara, observasi, dan studi literatur. Wawancara dilakukan terhadap pembuat serial "16 Days of Activism” yakni Hannah Al Rashid, narasumber ahli, juga masyarakat yang telah menonton serial tersebut hingga selesai. Sedangkan observasi dilakukan terhadap dokumentasi film serta interaksi yang terjadi terkait dengan pendistribusian film ini di YouTube. Studi literatur dilakukan untuk melengkapi baik mendukung, memperkuat, atau mendapatkan perbandingan dari dari dokumen atau literatur.

\section{HASIL DAN PEMBAHASAN}

Berdasarkan perolehan data terkait isu selebriti dalam digital activism tentang kekerasan terhadap perempuan di YouTube, bagian ini akan membahas empat sub bahasan. Pertama akan dibahas kekuatan yang dimiliki oleh seorang Hannah Ar Rashid terkait dengan advokasi tentang isu kekerasan terhadap perempuan. Selanjutnya dibahas strategi media yang digunakan untuk melakukan advokasi melalui digital dalam hal ini adalah menggunakan film sebagai kemasan kontennya dan YouTube sebagai saluaran distribusinya. Pada bagian ketiga dibahas bagaimana keterlibatan para selebritis dalam film “\#16 Days Activism2017' sebagai digital activism. Setelah itu di bagian akhir bab ini terdapat sub bab yang membahas sikap khalayak terkait Keterlibatan Selebritis dalam Film '16 Days Activism' dan penyebarluasannya di YouTube. 
Kekuatan Aktor dan keterlibatannya dalam Advokasi Kekerasan Terhadap Perempuan

Kompleksitas yang dipahami Hannah terkait dengan tindak kekerasan terahadap perempuan adalah terkait dengan kekerasan yang terjadi di dalam rumah tangga dan hubungan dekat atau masa pacaran. Menurut Hannah, ketika seorang perempuan mengalami kekerasan - dalam hal ini istri - maka korban tidak dapat semerta-merta pergi meninggalkan pelaku suami, ayah, saudara, pacar, dan lain-lain karena terikat pada hubungan keluarga yang mengikat mereka.

Sebagai seorang perempuan kelas menengah atas Hannah mendapatakan pendidikan yang memadai bahkan berlebih dibanding perempuan seusianya di Indonedia. Hannah yang lahir dan dibesarkan di Eropa kemudia menempuh pendidikan tinggi dalam Indonesia and Development Studies di SoAS, School of Oriental and African Studies di University of London. Berdasarkan pendidikan yang diambilnya selain belajar tentang sastsra Indonesia dia juga belajar tentang pembangunan terkait aspek ekonomi, politik sosiologi dan anthropologi. Latar belakang pendidikannya sangat mempengaruhi keinginan Hannah untuk kembali ke Indonesia sebagai negara berkembang dan tempat asal ayahnya -bugissmenetara ibunya orang perancis. Hannah menyadari negaranya masih harus terus dibangun untuk meningkatkan kehidupan rakyatnya baik dalam konteks kesejahteraan maupun keadilan.

Setelah menyelesaikan sekolah di SoAS dan pindah ke Indonesia dan Hannah berniat bekerja di sebuah lembaga internasional yang menangani berbagai bidang sosial. Akan tetapi pekerjaan yang diharapkannya tidak muncul dan pada akhirnya ia terjun ke industri hiburan. Ketertarikannya terhadap isu gender dan hak perempuan mendorong dirinya menerima tawaran sebagai SDG Mover dari UN untuk bidang 'gender equality'. Alasan lain adalah hal itu dianggap relevan dengan latar belakang studi yang diambilnya serta tujuannya pindah ke Indonesia.

Ketertarikan Hannah pada isu gender dianataranya juga didasarkan pada pengalamannya sebagai korban cat calling, pelecehan seksual di jalanan, di tempat kerja dan kekerasan dalam hubungan dengan pasangannya. Pertama kali dia berani mengungkapkan pengalamannya sebagai korban kekerasan adalah melalui artikel yang ditulisnya untuk Magdalene.co. Setelah itu dia merasa bahwa pengalamannya sebagai korban penting untuk disebarkan pada khalayak agar lebih memahami kasus kekerasan terhadap perempuan yang menurutnya lebih banyak terjadi di Indonesia dibanding di Eropa.

Merujuk pada pengalamannya sebagai survivor dan aktivis, Hannah ingin memberikan gambaran tentang kasus kekerasan terhadap perempuan dari sudut pandang korban. Dia ingin memberi pemahaman kepada khalayak bahwa solusi dari masalah kekerasan terhadap perempuan tidak bisa ditentukan dengan mudah. Untuk menyelesaikan permasalah kekerasan terhadap perempuan diperlukan pertimbangan dari aspek-aspek yang mengikat perempuan sebagai korban seperti keluarga, kondisi keuangan, psikologis, dan lain-lain. Di dalam ungkapannya Hannah menegaskan bahwa: 
"It's not a simple issue - it's a very complex issue. Jadi aku berharap orang bisa lihat dari sudut pandang yang bener. Tetep, what I want to make is.. one, it's a very serious issue. One in three women experienced this kind of stuff. So it's a serious issue."

Hasil wawancara Hannah Al Rashid, Sutradara Serial "\#16 Days Activism2017" pada 15 Maret 2018.

Sebagai selebritis dia memiliki pergaulan dan jaringan dengan para selebritis yang juga pernah menjadi korban kekerasan terhadap perempuan maupun yang tertarik menjadi bagian dari upaya melawan tindak kekerasan terhadap perempuan. Bagi Hannah upaya melibatkan para selebritis dengan pengalaman dan ketertarikan seperti itu tidaklah sulit. Sebagai seorang selebriti dan juga aktivis, teman-temannya dapat dengan mudah mempercayai dan tertarik pada ajakan Hannah baik langsung maupun tidak langsung dalam kegiatan advokasi di bidang kekerasan terhadap perempuan. Keterlibatan selebritis pada advokasi tersebut memberi peluang besar untuk dapat mengangkat isu kekerasan terhadap perempuan menjadi wacana publik dan menarik perhatian lebih banyak orang.

Penggunaan Film dan YouTube sebagai Media Advokasi

Permasalahan terkait dengan isu tentang kekerasan terhadap perempuan merupakan isu yang marjinal karena menyangkut hal yang terkait dengan tabu, rasa malu, dan memalukan. Hal yang paling disayangkan adalah ketika isu kekerasan terhadap perempuan yang hadir di media umumnya hanya terkait dengan peristiwapersitiwa kekerasan terhadap perempuan dan pelaporan tentang korban serta perlakuan yang mereka terima. Pemberitaan yang dilakukan pun umumnya menempatkan perempuan seolah-olah yang memicu atau memberi kesempatan pada pelaku. Pemberitaan akan memuat perempuan yang berteman atau memiliki hubungan tertentu dengan laki-laki yang kemudian menjadi pelaku, perempuan yang melakukan aktivitas di luar rumah di malam hari atau perempuan yang berpakaian tertentu yang berkonotasi negatif. Liputan media tersebut tidak saja meremehkan akan tetapi juga menjadikan korban mengalami reviktimisasi (memperlakukan korban kekerasan sehingga dia menjadi korban kembali, dalam cara yang berbeda seperti disalahkan atau dilecehkan).

Oleh karena itu advokasi terkait tentang kekerasan terhadap perempuan memerlukan ruang alternative untuk memberitakan atau menyebarluaskan isu tentang kekerasan terhadap perempuan yang tidak menjadikan perempuan sebagai korban yang dipersalahkan. Untuk mencari ruang baru saat media arus utama dikuasai oleh cara pandnag dan nilai-nilai baru maka media berbasis internet atau media digital menjadi alternatif yang potensial. Media digital atau media baru tidak saja mampu memberi ruang untuk bergam isu akan tetapi juga peluang untuk siapapun terlibat dalam proses produksi dan distribusi pesan bukan hanya sebagai konsumen isi media. Hal ini yang juga ditangkap oleh Hannah dalam upayanya melakukan advokasi tentang isu perempuan. Media baru khususnya media sosial sebagai suatu yang tidak saja familiar bagi diri Hannah akan tetapi juga bagi khalayak yang ingin dijadikan target sasaran advokasinya. Hannah telah memiliki Instagram, 
Twitter, dan memiliki channel YouTube yang berisi beberapa video yang dia sharing sebagai selebritis. Instagram Hannah memiliki follower tidak kurang dari $160 \mathrm{k}$ folowers dan Twitter sebanyak 34,3k followers. Sementara saluran YouTtube yang berisi video tentang kegiatan pribadinya juga memiliki viewer belasan ribu viewer dengan beragam kegiatan yang di sharing. Artinya media sosial bagi Hannah menjadi salah satu salurannya berinteraksi dengan banyak orang atau peluang bagi dirinya untuk menjangkau khalayak yang cukup luas.

Advokasi tentang kekerasan terhadap perempuan menyangkut banyak hal misalnya tentang bagaimana jenis-jenis yang merupakan aktivitas yang termasuk kekerasan terhadap perempuan, bagaimana masyarakat menilai kejadian kekerasan terhadap perempuan, bagaimana korban menyikapi kekerasan yang dialaminya, apa yang harus dilakukan sebagai korban kekerasan terhadap perempuan, dan bagaimana pelaku seharusnya ditindak. Penjelasan tentang semua hal tersebut membutuhkan informasi dan penjelasan yang cukup panjang sehingga perlu dikemas agar khalayak sasaran tetarik dan bersedia memberikan perhatian hingga mau meluangkan waktunya untuk memahami hal-hal tersebut.

Hannah memilih format film atau video untuk advokasi tentang kekerasan terhadap perempuan dengan alasan pertama karena menurutnya era sekarang era vloging dan digital. Selain itu dia sangat mencintai film dan menurut Hannah video atau film juga memiliki kekuatan sebagai media. Alasan lainnya adalah karena isi atau materi yang ingin disampaikan terkait isu kekerasan terhadap perempuan bukanlah isu yang mudah. Isu ini selain harus dikemas secara menarik akan tetapi juga harus memiliki cara penyampaian yang jelas dan tidak menimbulkan salah persepsi. Hal ini diungkapkan Hannah dalam pernyataan panjang berikut;

Saya ngerasa dengan era vlogging dan digital era ini.. memang udah paling cocok bikin video. dan mungkin karena saya juga orangnya.. I love film, right? Jadi, for me, medium video itu lebih powerful, maksudnya.. they say, a picture paints a thousand words. But in a video, you get all those words very clearly, you know what I mean? Then, supaya orang juga tidak salah paham, kan yang kita udah liat, banyak orang yang salah paham kalau kita ngomongin hal ini. Kalau nonton video.. seharusnya lo cukup bisa melihat orang ini bullshit atau engga, orang ini tulus atau engga, orang ini ngomong bener-bener apa yang keluar dari katanya - gak ada yang diedit-edit gimana gitu.."

Hasil wawancara Hannah Al Rashid, Sutradara Serial "16 Days of Activism" pada 15 Maret 2018

Pemilihan YouTube sebagai platform dalam advokasi filmnya juga didasarkan pada pertimbangan yang dilakukan terkait dengan materi yang akan disampaikan yaitu advokasi tentang kekerasan terhadap perempuan. YouTube dibanding media sosial lain seperti Instagram atau Twitter lebih memungkinkan atau lebih sesuai dengan film yang dibuat. Film advokasi yang dibuat relatif panjang dan terdiri dari 16 seri. Menurut Hannah hal itu tidak sesuai untuk instagram maupun Twitter seperti penjelasan Hannah berikut "

So, YouTube is because it's the platform that allows you to make longer videos. This is an issue that actually that we need to talk.. we need to make the camera roll for a long time.. and allows people to talk tanpa dipotong-potong terus. Jadi kalau untuk di Instagram 
paling teaser aja, link in bio, the typical way.. Dan, ya.. that's why YouTube. YouTube allows for longer content.

Hasil wawancara Hannah Al Rashid, Sutradara Serial "16 Days of Activism" pada 15 Maret 2018

Film yang dibuat berdurasi cukup panjang karena seperti yang diungkapkan Hannah dalam pernyataannya di atas, film itu harus menyampaikan pemikiran atau pengalaman dengan jelas sehingga tidak menghasilkan cara pandang atau bahkan stereotip yang salah terkait dengan isu perempuan. Pemikiran ini sangat tepat apabila merujuk pada penelitian HoustonKolnik dan kawan-kawannya. Hasil penelitian mereka menemukan bahwa terdapat advokasi melalui media tentang tracfiking yang ternyata mengandung salah persepsi dan memunculkan stereotip yang buruk terhadap perempuan dalam kasus tracfiking (Houston-Kolnik, Soibatian \& Shattell, 2017; 25).

Setelah menentukan format konten, pertimbangan lainnya adalah terkait distribusi yang akan dilakukan melalui YouTube. Dimanakah film original akan di upload? Pertama-tama dengan pertimbangan formal maka channel YouTube UN menjadi pilihan. Selain itu apabila lebih khsusus sebagai bagian dari project UN dalam isu perempuan maka film yang dihasilkan juga dapat di upload melalui UN Woman. Akan tetapi karena viewer dan subscriber dalam saluran You Thube Hannah jauh lebih besar jumlahnya dibanding yang dimiliki UN maupun UN Woman dianggap kurang populer. Hannah sudah memiliki channel YouTube yang rata-rata memiliki viewer cukup banyak (sekitar 16.000) dan juga dengan subscribernya yang cukup tinggi (sekitar 3,2k).
Berdasarkan data-data tersebut maka diputuskan film original yang akan dihasilkkan diupload di saluran YouTube milik Hannah Ar Rashid agar menjangkau khalayak sasaarn yang lebih banyak. Setelah di upload di saluran YouTube Hannah maka link nya akan disebarkan atau di share pula oleh para agen lainnya.

Menurut salah seorang produser kenalan Hannah yang memiliki kerjasama dengan YouTube, dikatakan bahwa YouTube juga menyukai konten yang panjang seperti pada video VICE yang kadang-kadang mencapai 3045 menit -sesuai dengan panjang film advokasi-. YouTube juga mudah di akses dan dengan mudah link YouTube juga kemudian dapat di post di berbagai platform media sosial lainnya. Selain itu hal ini juga terkait dengan para millennials yang menjadi aktor dalam film yang diproduksi diantaranya Refal dan Sheryl. Mereka punya kekuatan yang luar biasa dalam media digital atau format online video. Episodenya saat dilaunching pertama kali paling banyak ditonton dalam satu hari. Para milenials ini sangat antusias dan berusaha semaksimal yang mereka bisa. Hannah merasa perlu menyampaikan hal tersebut pada Sheryl dan ketika dikatakan "Babe, you have power. Use your voice," dan Sheryl menjawab "yes I'll do more”. Bagi Hannah anak-anak muda seperti itu adalah sumber daya yang hebat dan penting. Oleh karena itu penggunaan YouTube sebagai media digital juga menjadi pilihan yang dianggap sesuai dengan sasaran advokasi kekerasan terhadap perempuan yang dilakukan melalui film “\#16 Days Activism 2017” 
Selebritis dan Film'16 Days Activism' sebagai Digital Actibvism

Film yang berjudul “\#16 Days Activism2017" dibuat oleh Hannah Al Rashid untuk mengangkat isu tentang kekerasan terhadap perempuan kepada khalayak yang lebih luas. Hal itu dilatarbelakangi kesadaran yang dimilikinya terkait dengan kekerasan terhadap perempuan dan upaya untuk melawannya dan keinginannya untuk menyebarluaskannya kepada khalayak. Sejak awal, Hannah memang sudah merencanakan untuk mengajak teman-teman dekat sesama selebritis selain para aktivis perempuan yang memperjuangkan isu ini agar lebih diketahui dan dipahami khalayak luas.

Proses pencarian talent dalam film "\#16 Days Activism2017" ini berlangsung tanpa kendala. Ada beberapa orang yang membatalkan atau memang menolak untuk ikut serta. Hannah sangat memahami keadaan ini karena nyatanya tidak semua orang, khususnya selebriti yang dikenal oleh banyak orang, berani untuk menyuarakan isu kekerasan terhadap perempuan yang masih sensitif. Masih banyak yang khawatir akan ada citraburuk yang terbentuk jika ikut ambil bagian dalam proyek ini.

Menurut Hannah proses rekrutmen dilakukan melalui berbagai upaya baik dengan hanya menjelaskan atau mempersuasi, bahkan melalui proses negosiasi maka Hannah berhasil merekrut talent dari para selebritis lainnya untuk terlibat dalam Film “\#16 Days Activism2017”. Proses rekrutment juga dilakukan melalui ajakan yang sifatnya berantai -seorang selebriti yang bersedia terlibat mengajak selebriti lainnya-. Hannah berhasil memilih sejumlah talent yang kemudian ikut serta dalam “\#16 Days
Activism2017". Berdasarkan seleksi yang dilakukan maka akhirnya Film “\#16 Days Activism2017" melibatkan 28 orang yang terdiri dari 24 selebritis -termasuk Hannah-, 3 aktivis dan 1 orang keluarga selebriti. Diantara 28 orang selebritis yang terlibat dalam film tersebut selain Hannah Ar rashid sebagian juga sudah dikenal sebagai aktivis diantaranya Dian Sastrowardoyo ndan Reza Rahardian.

Berdasarkan jumlah talents yang terlibat maka Hannah merancang 16 tayangan untuk kampanye selama 16 hari di bulan November sejalan dengan program Internasional maupun nasional gerakan perempuan yang dinamai "Kampanye 16 hari Anti Kekerasan terhadap Perempuan". Karena kampanye ini bersifat internasional maka judul film yang dibuat Hannah yaitu “\#16 Days Activism 2017” dibuat oleh berbagai kelompok dan dari berbagi negara dengan nama 16 Dayas Activism.. Untuk mengakses film yang diproduksi Hannah maka dapat diakses dengan mengetik \#16 Days Acivism2017 (1-16)".

Film Hannah di dalam setiap episode atau seri menghadirkan dua orang aktor atau aktris. Pemilihan pasangan juga disesuaikan dengan topik, alur perbincangan yang diinginkan serta kenyamanan masing-masing talent. Sebagai contoh pasangan Rio Pasaribu dengan Dian Sastrowardoyo pada episode 3 dipasangkan karena mereka adalah saudara sepupu. Perbincangan diantara mereka dirancang berlangsung lebih fleksibel, mengalir dan terkesan sebagai obrolan dalam sebuah keluarga. Sementara Sanita Rini dari Youth Coalition for Girls dan Vivi Restuviani dari Hollaback Jakarta dalam episode 6 dipasangkan karena mereka 
adalah sesama aktivis gerakan perempuan. Pembicaraan mereka di dalam episode yang mereka isi juga dirancang mencerminkan pandangan aktivis dan juga memudahkan kedua activist tersebut dalam membangun pembicaraan diantara mereka berdasarkan pengetahuan dan pengalaman yang relative sama.

Secara lebih detil gambaran seluruh talents baik selebritis maupun activist yang terlibat dan latar belakang atau pekerjaan mereka dapat dilihat dalam tabel berikut:

Tabel 1 Para Aktor dalam Film"\#16 Days of Activism 2017"

Para Aktor dalam Film"\#16 Days of Activism 2017"

\begin{tabular}{cll}
\hline Episode & \multicolumn{1}{c}{ Nama } & \multicolumn{1}{c}{ Keterangan } \\
\hline 1 & Reza Rahadian & Actor, SDGs Mover \\
\cline { 2 - 3 } & Dhian & Mother of Reza \\
& Matulessy & \\
\hline 2 & Kalis & Kolumnist \\
& Mardiasih & \\
\cline { 2 - 3 } & Devi Asmarani & $\begin{array}{l}\text { Editor-in-Chief } \\
\text { "Magdalene" }\end{array}$ \\
\hline 3 & Rio Pasaribu & Legal Consultant, \\
& & Co-Founder RUCI \\
& & Art Space \\
\cline { 2 - 3 } & Dian & Actor, Activist, \\
& Sastrowardoyo & Entrepreneur \\
\hline 4 & Ligwina & Stand-Up Comic, \\
& Hananto & Financial Trainer \\
\cline { 2 - 3 } & Hannah & Actress, SDG \\
& Rashid & Mover for Gender \\
& & Equality \\
\hline 5 & Julie Estelle & Actress, \\
& & Entrepreneur \\
\cline { 2 - 3 } & Cathy Sharon & Actress, Mother, \\
& & Entrepreneur \\
\hline 6 & Sanita Rini & Vice President of \\
& & Youth Coalition for \\
& & Girls \\
\cline { 2 - 3 } & Vivi & Activist Hollaback! \\
& Restuviani & Jakarta \\
\hline 7 & Joe Taslim & Actor \\
\cline { 2 - 3 } & Hannah Al & Actress, SDG \\
& Rashid & Mover for Gender \\
& & Equality \\
\hline \multirow{2}{*}{ Rosianna } & Pemimpin Redaksi \\
\hline
\end{tabular}

\begin{tabular}{|c|c|c|}
\hline & Silalahi & Kompas TV \\
\hline & $\begin{array}{l}\text { Nadine } \\
\text { Alexandra }\end{array}$ & $\begin{array}{l}\text { Actress, } \\
\text { Environmentalist }\end{array}$ \\
\hline \multirow[t]{2}{*}{9} & Lala Karmela & Musician \\
\hline & Mike Lewis & $\begin{array}{l}\text { Actor, TV } \\
\text { Personality }\end{array}$ \\
\hline \multirow[t]{2}{*}{10} & Kartika Jahja & Musisi, Aktivis \\
\hline & Yacko & $\begin{array}{l}\text { Rapper, College } \\
\text { Lecturer }\end{array}$ \\
\hline \multirow[t]{2}{*}{11} & Arie Kriting & Comedian \\
\hline & $\begin{array}{l}\text { Hannah Al } \\
\text { Rashid }\end{array}$ & $\begin{array}{l}\text { Actress, SDG } \\
\text { Mover for Gender } \\
\text { Equality }\end{array}$ \\
\hline \multirow[t]{2}{*}{12} & Aldi Indrajaya & Fashion Stylist \\
\hline & Salvita Decorte & Painter, Actress \\
\hline \multirow[t]{2}{*}{13} & $\begin{array}{l}\text { Meira } \\
\text { Anastasia }\end{array}$ & Mother, Writer \\
\hline & Ernest Prakasa & Comedian \\
\hline \multirow[t]{2}{*}{14} & Agni Pratistha & $\begin{array}{l}\text { Founder of ARK } \\
\text { Motion Images, } \\
\text { Putri Indonesia } \\
2006\end{array}$ \\
\hline & Sigi Wimala & $\begin{array}{l}\text { Founder and } \\
\text { Creative Director of } \\
\text { Gerak Plus }\end{array}$ \\
\hline \multirow[t]{2}{*}{15} & Refal Hady & Actor \\
\hline & $\begin{array}{l}\text { Sheryl } \\
\text { Sheinafia }\end{array}$ & Musician, Actress \\
\hline \multirow[t]{3}{*}{16} & $\begin{array}{l}\text { Nadine } \\
\text { Alexandra }\end{array}$ & $\begin{array}{l}\text { Actress, } \\
\text { Environmentalist }\end{array}$ \\
\hline & Hannah Al & Actress, SDG \\
\hline & Rashid & $\begin{array}{l}\text { Mover for Gender } \\
\text { Equality }\end{array}$ \\
\hline
\end{tabular}

Isu yang diangkat dalam setiap episode berbeda-beda tanpa ada scenario dialog yang ketat. Hannah yang juga sebagai sutradara hanya memberikan arahan singkat agar setiap talent menceritakan pandangan mereka mengenai isu kekerasan terhadap perempuan. Karena setiap orang memiliki pandangan yang berbeda maka perspektif yang diberikan akhirnya juga menjadi beragam, seperti dalam pernyataannya: "I wanted it to be as varied as possible... I also wanted it to have as many men as possible... I wanted it to cross-over different industries and generations..." (Hasil wawancara Hannah Al 
Rashid, Sutradara Serial "16 Days of Activism" pada 15 Maret 2018).

Isu kekerasan terhadap perempuan adalah isu yang terus menerus disuarakan oleh aktivisaktivis di seluruh belahan dunia. Berbagai aksi dan gerakan telah dibuat untuk terus memberikan pemahaman agar kekerasan terhadap perempuan dapat diminimalkan atau bahkan dihapus. Butuh usaha yang besar dan panjang hingga tujuan tersebut dapat benar-benar terealisasikan, salah satunya adalah dengan menggunakan suara-suara yang telah memiliki pengikut, selebriti misalnya.

Selanjutnya terkait dengan keterlibatan selebritis laki-laki dalam advokasi kekerasan terhadap perempuan, Hannah mengungkapkan alasan-alasannya dan diantaranya adalah bahwa perempuan akan hidup bersama dengan laki-laki dan sebagian besar pelaku kekerasan terhadap perempuan juga adalah laki-laki. Maka dari itu, perlu adanya edukasi kepada laki-laki untuk berani berbicara mengenai kekerasan terhadap perempuan, memahami bagaimana kekerasan dilihat dari sudut pandang seorang perempuan, dan tidak menjadikan isu ini tabu untuk diperbincangkan.

Oleh karena itu Hannah sebagai produser serta sutradara sangat memperhitungkan perlunya keterlibatan laki-laki dalam proses advokasi kekerasan terhadap perempuan. Sebanyak 16 orang laki-laki dari 28 yang terlibat dalam film tersebut atau dengan kata lain lebih dari 50\% aktor advokasi ini adalah laki-laki. Hal ini sejalan dengan penelitian yang menemukan bahwa keterlibatan laki-laki terkait dengan isu perempuan sangat penting untuk mengubah cara pandang laki-laki terkait dengan isu kekerasan terhadap perempuan (Maryani, Rakhmawan, Preciosa, 2017).

Melalui pernyataan lain Hannah menegaskan bahwa "Laki-laki kan harus be on our side. Kita gak bisa fight ini sendiri. Artinya perlawanan terhadap tindak kekerasan terhadap perempuan pada dasarnya bukan perseteruan antara laki-laki dan perempuan akan tetapi upaya memerangi pelanggaran kemanusiaan. Hal tersebut bukan hanya masalah perempuan akan tetapi masalah kemanuasiaan baik laki-laki maupun perempuan. Selain itu Hannah menegaskan laki-laki harus dilibatkan karena perempuan juga hidup bersama dengan laki-laki baik sebagai ayah, suami, kakak, adik maupun seornag ibu dari laki-laki. Rasa kasih sayang di antara ikatan perempuan dengan para laki-laki tersebut tentu saja tidak saja punya potensi untuk menjadi pelaku akan tetapi juga berpotensi juga menjadi korban ketika anak, isteri, ibu, atau saudaranya jadi korban.

Laki-laki yang juga menjadi pelaku perlu dilihat lebih jernih artinya kita harus memahami dalam cara pandang positif bahwa mereka tidak menyadari bahwa apa yang mereka lakukan pada perempuan menyakiti perempuan. Kuatnya nilainilai patriarki yang hidup di masyarakat menyebabkan laki-laki dibesarkan dengan cara dan nilai-nilai patriarki yang secara tidak langsung mensubordinat perempuan yang kemudian kadangkala menjadikan perempuan hanya sebagai objek bukan subjek.

Selebriti lain yang terlibat dalam film “\#16 Days of Activism 2017” menyatakan bahwa banyak laki-laki yang suka melakukan catcalling (a loud, sexually suggestive call or comment directed at someone publicly (as on the street)- 
panggilan atau komentar yang keras bernuansa seksual dan dilakukan terhadap sesorang biasanya di jalan. Menurut Arie Kriting seringkali sebenarnya laki-laki menganggap itu cara mereka mengungkapkan ketertarikan mereja pada perempuan. Berdasarkan ungkapan tersebut maka dapat dimaknai bahwa laki-laki seringkali melakukan sesuatu tindakan tanpa memahami bahwa perempuan tidak merasa nyaman dengan ucapan atau tindakannya tersebut.

Selanjutnya merujuk pada pendapat Arie Kriting yang diungkapkan dalam salah satu episode film, maka dalam pergaulan laki-laki dan perempuan seharusnya laki-laki mengetahui cara-cara berinteraksi yang lebih sesuai dan memberi kenyamanan pada perempuan. Artinya terdapat cara-cara interaksi laki-laki terhadap perempuan yang sudah mengakar dan tersosialisasi di masyarakarat akan tetapi tanpa disadari mengandung nilai patriarki yang memandang perempuan sebagai sub ordinat lakilaki, sehingga tanpa disadari seringkali juga memperlakukan perempuan seperti objek atau membuat perempuan tidak nyaman. Perempuan seharusnya adalah sosok yang dianggap pantas mendapat atau menerima perlakuan laki-laki sebagai subjek bukan sebagai objek, seperti objek penilaian, objek tontonan, atau objek seksual.

Permasalahan terkait cara pandang terhadap perempuan sebagai objek juga diungkapkan oleh Ernest Prakasa yang mengatakan bahwa ada unsur sejarah yang membuat laki-laki akhirnya terbiasa memandang perempuan sebagai objek dan masih terbawa hingga ke peradaban yang modern ini. Pandangan tersebut adalah salah dan menjadi satu hal yang tidak boleh diteruskan kepada lakilaki generasi selanjutnya. Pandangan yang dimaksud oleh Ernest itulah yang dinamakan sebagai nilai-nilai dalam budaya patriarki.

\section{Sikap Khalayak Terhadap Keterlibatan Selebriti dalam Film "16 Days of Activism"}

Seorang selebriti dipilih menjadi bintang iklan suatu merek karena ia memiliki pengikut yang sesuai dengan pasar dari merek tersebut. Seorang selebriti dipilih menjadi duta sebuah kampanye karena dianggap memiliki kredibilitas, citra, serta minat yang sesuai dengan yang dimilikinya. UNDP Indonesia memilih beberapa selebriti Indonesia untuk ikut serta mengampanyekan Sustainable Development Goals (SDGs) sesuai minat masing-masing, seperti Reza Rahadian terkait pelestarian air, Eva Celia terkait isu-isu lingkungan, juga Hannah Al Rashid sebagai Sustainable Development Goals Mover.

Hannah bersama dengan rekan-rekannya yang juga kebanyakan adalah dari kalangan selebriti mencoba ikut mengampanyekan isu kekerasan terhadap perempuan. Hal ini rupanya ditanggapi sebagai hal yang baik oleh $\mathrm{N}$, salah satu penonton seri “\#16 Days of Activism 2017" yang dibuat Hannah yang juga korban kekerasan terhadap perempuan. "Suka sih, selain dapet informasi atau ilmunya, jadi nambah daftar nama seleb yang ini gue belum tau juga." (Hasil wawancara N, Penonton Serial "16 Days of Activism" pada 29 Mei 2018). Salah seorang viewer juga mengatakan bahwa representasi lakilaki dalam "16 Days of Activism" sudah cukup memuaskan rasa penasarannya tentang 
bagaimana sikap laki-laki terkait isu kekerasan terhadap perempuan ini.

Terlepas dari tingkat ketenaran yang berbeda-beda, keterlibatan selebriti dalam kegiatan digital activism seperti film “\#16 Days of Activism 2017" di YouTube ini telah memberikan gambaran tersendiri bagi khalayak bahwa kekerasan terhadap perempuan dapat terjadi kepada siapa saja dan dari kalangan manapun. "Yang gue kaget ada di serial itu sih Dian Sastro.. seorang Dian Sastro pernah dipegang-pegang juga ternyata di angkot." (Hasil wawancara N, Penonton Serial "16 Days of Activism” pada 29 Mei 2018).

Berdasarkan analisis terhadap 16 episode yang diputar ditemukan bahwa 5 episode yang memiliki penonton terbanyak adalah episode yang dibintangi oleh selebritis yang relatif lebih populer dibanding selebritis lainnya.

Tabel 2. Partisipan Penelitian

dalam produksi film untuk advokasi. Sementara dari aspek media maka YouTube adalah salah satu media digital yang mampu mempermudah advokasi melalui film dan sesuai dengan isu rumit yang harus disamapikan dalam tayangan yang relatif panjang.

Berdasarkan seluruh aktivitas baik dari tujuan awal yang ditetapkan, rancangan isi yang disusun serta sasaran yang dituju sampai pada perubahan pandangan yang diharapkan terjadi pada masyarakat dalam memandan kassu kekerasan terhadap perempuan maka aktivitas selebitis yang terlibat di film '\#16 Days of Activism 2017' dapat dikatakan sebagai bentuk digital activism. Akhirnya dapat disimpulkan pula bahwa keterlibatan selebriti mampu menjadi daya tarik bagi khalayak untuk diterpa, mengetahui dan memahami isu kekerasan terhadap perempuan dengan cara pandang yang tidak bias gender.

\begin{tabular}{ccll}
\hline \multirow{2}{*}{ Episode } & \multirow{2}{*}{$\begin{array}{c}\text { Jumlah } \\
\text { Views }\end{array}$} & \multicolumn{1}{c}{ Partisipan } \\
\cline { 3 - 4 } & \multirow{2}{*}{$6.3 \mathrm{k}$} & Reza Rahadian & \multicolumn{1}{c}{ Pekerjaan } \\
\cline { 3 - 4 } & & Dhian Matulessy & Ibu dari Reza \\
\hline 3 & $4.7 \mathrm{k}$ & Rio Pasaribu & Konsultan hukum \\
\cline { 3 - 4 } & & Dian Sastrowardoyo & Selebriti (aktor) \\
\hline \multirow{2}{*}{11} & $3.1 \mathrm{k}$ & Arie Kriting & Selebriti (comedian) \\
\cline { 3 - 4 } & & Hannah Al Rashid & Selebriti (aktor) \\
\hline 13 & $3.8 \mathrm{k}$ & Meira Anastasia & Selebriti (penulis) \\
\cline { 3 - 4 } & & Ernest Prakasa & Selebriti (komedian) \\
\hline 15 & $4.3 \mathrm{k}$ & Refal Hady & Selebriti (aktor) \\
\cline { 3 - 4 } & & Sheryl Sheinafia & $\begin{array}{l}\text { Selebriti (aktor, } \\
\text { penyanyi) }\end{array}$ \\
\hline
\end{tabular}

Penelitian ini merekomendasikan diginakan film dan YouTube sebagai media advokasi untuk beragam isu pada khalayak muda akan tetapi perlu kreatifitas dalam membuat format kemasan isi

Sumber: Hasil wawancara N, Penonton Serial "16 Days of Activism" pada 29 Mei 2018.

Sinergi sebagai survivor, selebriti dan juga aktivis menjadi kekuatan bagi Hannah Ar Rashid untuk mengangkat wacana tentang kekerasan terhadap perempuan dan melibatkan selebriti lain atau genrenya agar dapat diterima mereka. Perkembangan pesat penggunaan media sosial di Indonesia, fil yang disebarkan melalui YouTube berpotensi untuk memperluas jangkauan advokasi tentang isu kekerasan terhadap perempuan pada berbagai kalangan terutama kaum muda baik di perkotaan maupun pedesaan. 


\section{SIMPULAN}

Sinergi sebagai survivor, selebriti dan juga aktivis menjadi kekuatan bagi Hannah Ar Rashid untuk mengangkat wacana tentang kekerasan terhadap perempuan dan melibatkan selebriti lain dalam produksi film untuk advokasi. Sementara dari aspek media maka YouTube adalah salah satu media digital yang mampu mempermudah advokasi melalui film dan sesuai dengan isu rumit yang harus disamapikan dalam tayangan yang relatif panjang.

Berdasarkan seluruh aktivitas baik dari tujuan awal yang ditetapkan, rancangan isi yang disusun serta sasaran yang dituju sampai pada perubahan pandangan yang diharapkan terjadi pada masyarakat dalam memandan kassu kekerasan terhadap perempuan maka aktivitas selebitis yang terlibat di film '\#16 Days of Activism 2017' dapat dikatakan sebagai bentuk digital activism. Akhirnya dapat disimpulkan pula bahwa keterlibatan selebriti mampu menjadi daya tarik bagi khalayak untuk diterpa, mengetahui dan memahami isu kekerasan terhadap perempuan dengan cara pandang yang tidak bias gender.

Penelitian ini merekomendasikan diginakan film dan YouTube sebagai media advokasi untuk beragam isu pada khalayak muda akan tetapi perlu kreatifitas dalam membuat format kemasan isi atau genrenya agar dapat diterima mereka. Perkembangan pesat penggunaan media sosial di Indonesia, fil yang disebarkan melalui YouTube berpotensi untuk memperluas jangkauan advokasi tentang isu kekerasan terhadap perempuan pada berbagai kalangan terutama kaum muda baik di perkotaan maupun pedesaan.

\section{DAFTAR PUSTAKA}

Adiputra, Wisnu Martha, 2012. Media Baru ; Studi Teoritis \& Telaah dari Perspektif Politik dan Sosiokultural, FISIPOL, Universitas Gajah Mada, Yogyakarta.

Creswell, J. W. (2007). Qualitative inquiry and research design: Choosing among five approaches (2nd ed.). California: Sage Publications, Inc.

Denzin, N.K., \& Lincoln, Y.S. (2005). The discipline and practice of qualitative research. In The Sage Handbook of Qualitative Research (Denzin, N. and Lincoln, Y. eds.). Thousand Oaks CA: Sage Publication

Driessens, O. (2013). Celebrity Capital: Redefining Celebrity Using Field Theory. Journal Theory and Society, 42(6), 543-560.

Grigoriadis, V. (2005). Celebrity and its discontents - a diagnosis. New York Magazine, 37, 34-38.

Harkriswono, H. (2000). Hukum Pidana dan Kekerasan Terhadap Perempuan. Bandung: PT. Alumni.

Houston-Kolnik, D Jaclyn, Cristina Soibatian, Mona M Shattel, (2017). Advocates'Experience With Media and the Impact of Media on Human Trafficking Advocacy, Journal of Interpersonal Violence 125/2017/DOI:10.177/088620517692337/journa ls.sagepub.com/home/ji

Joyce, M. (2010). Digital Activism Decoded: the New Mechanics of Change. New York: International Debate Education Association.

Jurriens, Edwin, \& Ross Tapsell, 2017. Digital Indonesia; Connectivity and Divergence, ISEAS Publishing, Simgapore.

Karatzogianni, A. (2015). Firebrand Waves of Digital Activism 1994-2004: The Rise and Spread of Hacktivism and Cyberconflict. London: Palgrave Macmillan.

Kelompok Kerja "Convention Watch" Pusat Kajian Wanita dan Gender Universitas Indonesia. (2000). Pemahaman Bentukbentuk Tindak Kekerasan Terhadap Perempuan dan Alternatif Pemecahannya. Jakarta: PT. Alumni. 
Komnas Perempuan. (2018). Catatan Tahunan Komnas Perempuan 2018. Jakarta: Komnas Perempuan.

Lim Merlyna (2013) Many Clicks but Little Sticks: Social Media Activism in Indonesia, Journal of Contemporary Asia, 43:4, 636-657. DOI: 10.1080/00472336.2013.769386.

Maryani, Eni, (2011), Media dan Perubahan Sosial: Suara Perlawanan Melalui Radio Komunitas, Rosda Karya, Bandung. , Eni \& Justito Adiprasetio, (2017). Magdalene.co Sebagai Media advokasi Perempuan, Jurnal Ilmu Komunikasi, UAJY, Vol. 14, No. 1, Juni 2017111124, Universitas Atmajaya Yogyakarta, Yogyakarta.

, Eni \& Justito Adiprasetio, (2017). Literasi .co Media Alternatif bagi Kalangan Marjinal dan Grass Root, Laporan Penelitian, Pusat studi Media dan Budaya Universitas padjadjaran, Sumedang.

........., Eni, Detta rahmawan, Preciosa Alnashava (2017), Aliansi Laki-laki Baru sebagai Keterlibatan laki-laki dalam Advokasi Gender", Laporan Penelitian, Pusat studi Media dan Budaya Universitas padjadjaran, Sumedang.

, Eni (2018). Developing Social Solidarity through Digital Media, Jurnal Komunikasi ISKI, Vol. 03 (01), 2018. 12-17

http://dx.doi.org/10.25008/jkiski.v3i1.14 $\underline{4}$

Montiel, Aimée Vega (2015). News Media Coverage of Women, Asia Pacific Media Educator 25(2) 182-193 2015 University of Wollongong, Australia SAGE Publications DOI:10.1177/1326365 X15604260 http://ame.sagepub.com

Rojek, C. (2001). Celebrity. London: Reaktion Books.

Shah, V., Sivitanides, M., \& Mehta, M. (2011). The Era of Digital Activism. Conference for Information System, Conference for Information Systems Applied Research (CONISAR) Proceedings, 4(1842), 1-8.

Yin, Robert K (2000). Studi Kasus Desain dan Metode, Jakarta: Raja Grafindo Persada 